Article title: Covid-19's Emotional Toll on Students: Experiences during Online Assessments in an Open and Distance Learning Programme

Authors: Elize du Plessis[1], Gert van der Westhuizen[2]

Affiliations: University of South Africa[1]

Orcid ids: 0000-0003-4299-4632[1], 0000-0002-4472-652X[2]

Contact e-mail: dplesec@unisa.ac.za

License information: This work has been published open access under Creative Commons Attribution License http://creativecommons.org/licenses/by/4.0/, which permits unrestricted use, distribution, and reproduction in any medium, provided the original work is properly cited. Conditions, terms of use and publishing policy can be found at https://www.scienceopen.com/.

Preprint statement: This article is a preprint and has not been peer-reviewed, under consideration and submitted to UnisaRxiv for open peer review.

Funder: N/A

DOI: $10.25159 /$ UnisaRxiv/000011.v1

Preprint first posted online: 03 June 2021

Keywords: emotions, higher education, online learning, PGCE 


\section{Covid-19's Emotional Toll on Students: Experiences during Online Assessments in an Open and Distance Learning Programme}

Elize C. du Plessis

https://orcid.org/0000-0003-4299-4632

University of South Africa

dplesec@unisa.ac.za
Gert J. van der Westhuizen

https://orcid.org/0000-0002-4472-652X

University of South Africa

\section{Abstract}

The Covid-19 pandemic had an immense effect on teaching and learning during 2020. The fast shift to online examinations in reaction to the pandemic and subsequent lockdown underlines the significance of motivationally enriched and emotionally supportive instruction during this stressful time. It cannot be assumed that all students have the same access to online assets or to internetequipped devices such as laptops or tablets. Not all students coped well, as an analysis of student remarks indicated in a qualitative study. The purpose of this exploratory case study was to determine what type of emotions Postgraduate Certificate in Education students experienced during their first fully online examination in order to create motivating and supportive learning environments. A total of 10 of these students from an open and distance learning university were purposefully selected to complete 14 questions related to their learning needs and, in particular, emotional challenges during the lockdown. Theoretical underpinnings include, inter alia, five motivational design principles. The results indicated that all 10 students had access to mobile phones and seven to laptops to participate in online academic activities. The emotions experienced most by the students varied from anxiousness to restlessness. The findings are discussed with reference to supporting students' motivation and emotions in university courses during these stressful times.

Keywords: emotions, higher education, online learning, PGCE

\section{Introduction}

Covid-19 demanded the sudden change to teaching in an online or distant mode by most universities in South Africa and also globally (Asma 2020; Moorhouse 2020). This means that numerous initial teacher education (ITE) programmes had to find means to facilitate tasks that had usually been done in a face-to-face manner such as the writing of venue-based examinations of these programmes.

Definitely, the introduction of technology to the "learning environment" adds a component of difficulty to students' emotional experience that may not have a face-toface or distance learning equivalence. Specially, in addition to undergoing emotion with 
regard to "attending class", learning and taking tests (Pekrun et al. 2011), students may moreover experience emotions in answer to the technology itself. This was verified with research by Butz, Stupnisky, and Pekrun $(2015,8)$ who found that when compared with on-campus learners, online students stated upper levels of "technology-related anger, anxiety and helplessness". This makes it more imperative than ever to think through the cause of the emotion, in addition to the emotion itself (Daniels and Stupnisky 2012).

Research has recognised the way in which positive emotions (for example, engagement and excitement) and negative emotions (for example, anger, frustration, confusion, boredom, and isolation) experienced by online learners, support or constrain the process of learning (see Conrad 2002; Hara and Kling 2003; Järvenoja and Järvelä 2005; O’Regan 2003; Rovai and Wighting 2005).

In the context of this research, students had an option in the past to submit assignments either by post or online, but most examinations were venue based. During 2020, students were forced to submit all assignments online and, in many cases, write their first fully online examination. This paper focuses on dealing with the following research question: What emotions associated with challenges experienced in an open and distance learning programme during the Covid-19 pandemic were experienced by students?

\section{Theoretical Underpinnings}

Emotions are significant in learning since they can either obstruct or inspire learning (Dirkx 2001; Yorks and Kasl 2002). Research on the emotions of online learning has concentrated on the prominence of learners' emotional state in relation to the sense of the context of learning (Hara and Kling 2003; Rovai and Wighting 2005), the way in which positive and negative emotions constrain or improve online education (Allan and Lawless 2003; Conrad 2002; O'Regan 2003), and the way in which the materials, variety and influence of learners' emotional experiences influence various expressions of online learning (Järvenoja and Järvelä 2005; Wosnitza and Volet 2005).

Research on the emotions of online learning similarly put emphasis on the meaning of emotional dimensions to online learning, maintaining that the possibilities of web-based education will not be grasped except when emotional aspects are appropriately recognised (Goldsworthy 2000; Spitzer 2001). MacFadden (2007) and MacFadden et al. (2005) recommended a constructivist model of web-based education highlighting the practise of emotion in e-learning, grounded in the theory that emotional stress may facilitate constructivist learning objectives.

A study done by Zembylas (2008) indicated that distance education students had to manage several accountabilities when adding postgraduate study to their already demanding lives, a reality that converted into extreme emotions during the year.

One way to motivate students and to reinforce positive emotions is to use the five motivational design principles suggested by Linnenbrink-Garcia, Patall, and Pekrun 
(2016). Subsequently, these principles combine theoretical and empirical work concentrated on motivation and emotion in education such as achievement goal theory (Urdan and Kaplan 2020), expectancy-value theory (Eccles and Wigfield 2020), control-value theory (Pekrun 2006), self-determination theory (Ryan and Deci 2020) and attribution theory (Graham 2020).

\section{Design Principle 1: Support Competence through Instruction, Challenging Work, Information and Feedback}

High-quality instruction as a rule is structured, well-paced, clear, and with examples. These are provided by teachers with subject matter, competence and positive and regular feedback. Various attribution strategies are available, such as giving testimony by peers of their personal experiences, or providing information that learning happens through appropriate strategy use.

\section{Design Principle 2: Support Students' Autonomy through Self-Decision and Self- Directing}

This design principle is accomplished by means of choices and active decision-making that allows students feeling autonomous when they express their opinions and perspectives.

\section{Design Principle 3: Select Personally Relevant Activities that Provide Identification and Involvement}

The key principle here is that students' value and interest are supported and that they engage in tasks which are interesting and relevant. Such tasks also support goal orientations.

\section{Design Principle 4: Emphasise Learning as opposed to Performance and Social Comparison}

This design principle aims to reduce performance goals. Strategies for enacting this principle include activities in which students receive formative assessments, have numerous opportunities to revise work, and are acknowledged for the effort they put into learning. The use of rubrics with clearly described criteria for evaluation can also help to shift the focus to learning.

\section{Design Principle 5: Support Feelings of Relatedness and Belonging between Students and Teachers}

Even if the intervention confirmation is limited, supporting feelings of belonging and relatedness between students and between students and lecturers likewise looks to be crucial. A positive connection of belonging with lecturers helps to enhance students' inherent motivation (Ryan and Grolnick 1986) and to rise their situational interest and apparent capability (Linnenbrink-Garcia, Patall, and Messersmith 2013). There moreover appear to be contagion paraphernalia, such that teacher keenness converts into 
students' feelings of delight (Frenzel et al. 2009). Fitting together with peers is also imperative. Students who feel joined to their fellow students report more positive emotional engagement (for example, enhanced interest, and reduced negative affects) (Furrer and Skinner 2003). This goal of generating and preserving connections through individuals in the teaching space lines up with the existing stress on social emotional learning (see Brackett and Rivers 2014) in numerous schools across the United States. This design principle may by now be supported in part by existing mediations.

\section{Methodological Choice}

An interpretive paradigm in nature was used and the following sections present the research design, selection of participants, the data collection and analysis.

\section{Research Design}

In this study we chose to use a qualitative approach that originated from our desire to gain an understanding of students' emotional experiences during online examinations. The qualitative research design chosen for this study was a single exploratory case study. The case study "allows investigators to retain the holistic and meaningful characteristics of real life events" (Yin 2009, 4). Yin (2009) states that the case study is often used when the purpose of the research is to answer how or why questions. Within the Postgraduate Certificate in Education (PGCE) ITE programme at the university, a group of 10 student teachers were purposefully selected to form the specific case. This case study was observed as influential as the question of concern was the participants' emotional experiences during their first online engagement. Zeichner $(1999,9)$ states that case studies in teacher education programmes have "provided a close-up and detailed look at particular teacher education activities and show what a teacher education program looks like from the inside, from the perspectives of students and faculty".

\section{Selection of Participants}

In this study, purposive participant selection, also called judgement participant selection, was used to intentionally choose participants who have certain assets and are situated in particular circumstances (Glesne 2006). A total of 10 PGCE student teachers who had completed their first fully online examination during the Covid-91 pandemic were invited to participate in the study.

Trustworthiness of a study is guaranteed once findings of the research study deliver the preferred responses, contribute to an understanding of and improve on the specific phenomenon. Olivia (2017) suggests that trustworthiness is to find that the research study's discoveries are credible, transferable, confirmable and dependable.

Ethical clearance was obtained from the university's ethical team. The first author sent a memo to all the requested participants via email clarifying the aim of the study and what would be necessary individually. The participants showed their agreement by 
signing a consent form and returning it to the first author via email. Participation was voluntary and any participant could withdraw at any time without providing reasons.

\section{Data Collection and Analysis}

Data collection was done by sending a questionnaire by email to the participants, which was in line with the distance education mode of delivery of this institution. An extensive literature study aided the construction of a questionnaire which was based on the "beliefs questionnaires" often used for research in the field of education (Hammer and Elby 2002; Hannaway et al. 2018). Apart from providing biographical information (questions 1 to 3 ), the participants were required to answer 11 open-ended questions (questions 4 to 14) (refer to Appendix A for the full questionnaire). The questions included rating the studying at students' place of residence during the Covid-19 pandemic; satisfaction with online academic activities; challenges, such as administration, student support, online learning, completing assignments or answering exam papers; tool(s) the students had access to in order to participate in online academic activities; services from the institution for online academic activities; ways to improve the students' online learning experiences during the lockdown; which emotions the students felt most often during these times; and what event or events caused these emotions most frequently.

When analysing the data, the procedures provided by Erlingsson and Brysiewicz (2017) were used for carrying out content analysis. The first phase of the content analysis involved reading and rereading the collected transcribed data. Line-by-line coding of the written answers on each individual questionnaire followed. The codes were units of meaning representing student answers per question item. The codes were then categorised across student answers and resulted in the development of main categories.

\section{Findings and Discussion}

A total of 20 students were purposefully selected and 10 volunteered to participate in the research. The ages of the four male and six female participants ranged between 22 and 38 years. Four main themes were identified in the categories emerging from the empirical data. The findings are presented under the identified themes, first by reflecting the voices of the participants, after which the data are interpreted and linked to the literature.

\section{Theme 1: Feelings of Happiness and Excitement are associated with Success and Receiving Results on Time}

The following two questions were asked: Rate how easy it is for you to study at your place of residence during the Covid-19 pandemic? How satisfied are you with online academic activities so far? 
The average of the values selected was six. Five participants were satisfied, four were neither satisfied or dissatisfied and one participant was dissatisfied with online activities.

Students were also asked which tool(s) they had access to in order to participate in online academic activities. All the participants indicated that they had mobile phones, seven had laptops, three had sufficient data for studies, five had access to the myUniversity Online Account/Portal, and only one participant had access to a teleconference account.

\section{Theme 2: Events Causing Stress and Anxiety Emotions include Technical Problems with Computers Malfunctioning, Examination Papers not Downloading and Delays in Receiving Results}

The question related to this theme was: With which aspects did you experience the most challenges, such as administration, student support, online learning, completing assignments or answering exam papers?

Challenges are listed from the most identified: Network problems - the system is often unavailable or slow; administrative and student support including answering phones, answering students' emails and financial services; downloading study material; receiving results and confirmation of qualifications completed; feedback on assignments; online exams and downloading exam papers; and updating personal details online.

Online lectures were identified as a service needed, mentoring, sufficient data and simplified examination instructions.

Theme 3: Most Students Reported Feelings of Restlessness, Worry, Anxiousness, and Concern over the Past Five Months

Theme 4: Responses to the Question how Students Deal with Emotions during Online Studies - Eight Students Indicated that they Share Emotions with Family and Friends

The responses to questions 12 to 14 are summarised in Table 1 . 
Table 1: Emotions experienced during online studies

\begin{tabular}{|c|c|c|c|}
\hline Participant & $\begin{array}{l}\text { Q12 In the past five } \\
\text { months, which } \\
\text { emotion did you } \\
\text { feel most often? } \\
\text { Happy; Content; } \\
\text { Excited; Restless; } \\
\text { Sad; Worried; } \\
\text { Angry }\end{array}$ & $\begin{array}{l}\text { Q13 What event or } \\
\text { events caused you to } \\
\text { feel that emotion } \\
\text { most frequently? }\end{array}$ & $\begin{array}{l}\text { Q14 Which response } \\
\text { best describes you in } \\
\text { academic work? Why? } \\
\text { I keep my emotions to } \\
\text { myself } \\
\text { I share my emotions } \\
\text { only with my family } \\
\text { I share my emotions } \\
\text { only with my friends } \\
\text { I share my emotions } \\
\text { with family and } \\
\text { friends }\end{array}$ \\
\hline 1 (Female (32)) & & $\begin{array}{l}\text { Submitting } \\
\text { assignments. }\end{array}$ & $\begin{array}{l}\text { I keep my emotions to } \\
\text { myself. I avoid others } \\
\text { celebrating my } \\
\text { misfortune. I tell my } \\
\text { emotions to my pillow. }\end{array}$ \\
\hline 2 (Male (38)) & & $\begin{array}{l}\text { Submitting online } \\
\text { exam. }\end{array}$ & $\begin{array}{l}\text { I share my emotions } \\
\text { only with my friends. }\end{array}$ \\
\hline 3 (Male (30)) & & $\begin{array}{l}\text { Uploading answered } \\
\text { papers on time and } \\
\text { receiving exam results } \\
\text { on time. }\end{array}$ & $\begin{array}{l}\text { I keep my emotions to } \\
\text { myself. I always } \\
\text { motivate myself when I } \\
\text { feel down, I strive for } \\
\text { excellence. }\end{array}$ \\
\hline 4 (Male (22)) & & $\begin{array}{l}\text { Feeling uncertain } \\
\text { about writing online } \\
\text { exams. } \\
\text { Laptop } \\
\text { malfunctioning. } \\
\text { Question papers not } \\
\text { downloading. } \\
\text { Questioning own } \\
\text { answers and ability. } \\
\text { Lecturers not } \\
\text { receiving online paper } \\
\text { or paper is corrupt. } \\
\text { Uncertainty about } \\
\text { materials delivery, } \\
\text { must print own study } \\
\text { material. }\end{array}$ & $\begin{array}{l}\text { I share my emotions } \\
\text { with family and friends, } \\
\text { especially when I have a } \\
\text { lot of stress on my } \\
\text { shoulders. This helps } \\
\text { me to receive different } \\
\text { perspectives from many } \\
\text { people I know. }\end{array}$ \\
\hline 5 (Female (33)) & & $\begin{array}{l}\text { Not receiving results. } \\
\text { Trying repeatedly to } \\
\text { resolve exam issue. } \\
\text { Waiting for exam } \\
\text { section to respond. }\end{array}$ & $\begin{array}{l}\text { I share my emotions } \\
\text { with family and friends, } \\
\text { because they are the } \\
\text { ones who give me } \\
\text { advice. }\end{array}$ \\
\hline 6 (Male (29)) & & $\begin{array}{l}\text { Waiting for the } \\
\text { university to respond } \\
\text { to queries. } \\
\text { University delaying } \\
\text { registration. }\end{array}$ & $\begin{array}{l}\text { I share my emotions } \\
\text { with family and friends, } \\
\text { because they are the } \\
\text { ones that are very close } \\
\text { to me and I normally go } \\
\text { to them when I need } \\
\text { some advice, enjoying } \\
\text { their help. }\end{array}$ \\
\hline
\end{tabular}




\begin{tabular}{|c|c|c|c|}
\hline Participant & $\begin{array}{l}\text { Q12 In the past five } \\
\text { months, which } \\
\text { emotion did you } \\
\text { feel most often? } \\
\text { Happy; Content; } \\
\text { Excited; Restless; } \\
\text { Sad; Worried; } \\
\text { Angry }\end{array}$ & $\begin{array}{l}\text { Q13 What event or } \\
\text { events caused you to } \\
\text { feel that emotion } \\
\text { most frequently? }\end{array}$ & $\begin{array}{l}\text { Q14 Which response } \\
\text { best describes you in } \\
\text { academic work? Why? } \\
\text { I keep my emotions to } \\
\text { myself } \\
\text { I share my emotions } \\
\text { only with my family } \\
\text { I share my emotions } \\
\text { only with my friends } \\
\text { I share my emotions } \\
\text { with family and } \\
\text { friends }\end{array}$ \\
\hline 7 (Female (34)) & & $\begin{array}{l}\text { Not knowing time } \\
\text { frames. } \\
\text { Feeling eager to start. } \\
\text { Concerns about } \\
\text { practical teaching and } \\
\text { many assignments. }\end{array}$ & $\begin{array}{l}\text { I share my emotions } \\
\text { only with my family. }\end{array}$ \\
\hline 8 (Female (31)) & & $\begin{array}{l}\text { Frustrated with delays } \\
\text { with results. } \\
\text { One module denying } \\
\text { me to get a job. }\end{array}$ & $\begin{array}{l}\text { I share my emotions } \\
\text { with family and friends. } \\
\text { I feel much better after } \\
\text { sharing than keeping to } \\
\text { myself. Advice and } \\
\text { words of courage from } \\
\text { them make me feel } \\
\text { better to continue with } \\
\text { my journey. }\end{array}$ \\
\hline 9 (Female (23)) & $\begin{array}{l}\text { Emotionally } \\
\text { exhausted and } \\
\text { overwhelmed } \\
\text { I am doing final year }\end{array}$ & $\begin{array}{l}\text { Being a final year } \\
\text { student and having } \\
\text { family pressuring, you } \\
\text { not want to fail. } \\
\text { Being only hope to } \\
\text { fight poverty. }\end{array}$ & $\begin{array}{l}\text { I share my emotions } \\
\text { with friends. }\end{array}$ \\
\hline 10 (Female (28)) & $\begin{array}{l}\text { Happy } \\
\text { Excited } \\
\text { Worried }\end{array}$ & $\begin{array}{l}\text { Passing modules made } \\
\text { me happy. } \\
\text { Additional } \\
\text { qualification will } \\
\text { make things better to } \\
\text { get a job. } \\
\text { Worried about not } \\
\text { having paid fees yet. }\end{array}$ & $\begin{array}{l}\text { I share my emotions } \\
\text { with family and friends. } \\
\text { When I need } \\
\text { motivation, they do not } \\
\text { hesitate. They are there } \\
\text { when I need advice } \\
\text { They celebrate with me. }\end{array}$ \\
\hline
\end{tabular}

From the responses given in Table 1, sharing emotions are done with self (2), family (1), friends (2), and family and friends (5).

\section{Conclusion and Recommendations}

This research was undertaken to explore the experiences of PGCE students who completed their first fully online examinations during the Covid-19 pandemic at a distance learning institution. 
The impression that the researchers got from the participants was that they experienced stressful times during their first fully online examination. We cannot accept that all students have equivalent access to online resources or to internet-equipped devices such as laptops or tablets. There are additional challenges too, such as online learning is challenging the technology structure of the university and its workforce.

This research has highlighted lessons learned during the experience of remote teaching during the pandemic. Just as lecturers and administrative staff learn more about a universal world of online learning, so the whole division will have to change. Just as universities and colleges are requesting their students to acquire different abilities, facts and understanding of the ways in which to learn, so educational staff will have to follow suit.

We argue that when sharing a course outline and expecting students to do online examinations, many students experience emotional challenges, struggle with learning design and need support. Individuals who believe that technology can substitute lecturers, particularly those who see false intellect as being able to do so, misinterpret the purpose and practice of teaching and learning in higher education.

We believe that the implications for the higher education environment is the exertion to notice innovative methods in which educational instructors can convey additional support, cooperation, and existence for their students.

In the light of the research results, it is recommended that reskilling of lecturers and instructors in modes of online teaching, assessment and mentorship be initiated. Administrative and student support have to be improved to create motivating and supportive learning environments.

\section{References}

Allan, J., and N. Lawless. 2003. "Stress Caused by Online Collaboration in E-Learning: A Developing Model.” Education and Training 45 (8/9): 564-72. https://doi.org/10.1108/00400910310508955.

Asma, A. D. 2020. "Covid-19: Universities Prepare to Switch to Remote Online Learning." Accessed 5 June 2020. https://www.timeslive.co.za/news/south-africa/2020-04-15-covid19-universities-prepare-to-switch-to-remote-online-learning/.

Brackett, M. A., and S. E. Rivers. 2014. “Transforming Students' Lives with Social and Emotional Learning." In International Handbook of Emotions in Education, edited by R. Pekrun and L. Linnenbrink-Garcia, 368-388. New York: Taylor and Francis.

Butz, N. T., R. H. Stupnisky, and R. Pekrun. 2015. "Students' Emotions for Achievement and Technology Use in Synchronous Hybrid Graduate Programmes: A Control-Value Approach." Research in Learning Technology 23: 1-16. https://doi.org/10.3402/rlt.v23.26097. 
Conrad, D. 2002. "Engagement, Excitement, Anxiety and Fear: Learners' Experiences of Starting an Online Course." American Journal of Distance Education 16 (4): 205-26. https://doi.org/10.1207/S15389286AJDE1604_2.

Daniels, L. M., and R. H. Stupnisky. 2012. "Not that Different in Theory: Discussing the Control-Value Theory of Emotions in Online Learning Environments." Internet and Higher Education 15 (3): 222-226. https://doi.org/10.1016/j.iheduc.2012.04.002.

Dirkx, J. M. 2001. "The Power of Feelings: Emotion, Imagination, and the Construction of Meaning in Adult Learning. New Directions for Adult and Continuing Education 89: 6372. https://doi.org/10.1002/ace.9.

Eccles, J. S., and A. Wigfield. 2020. "From Expectancy-Value Theory to Situated Expectancy-Value Theory: A Developmental, Social Cognitive, and Sociocultural Perspective on Motivation." Contemporary Educational Psychology. 61. https://doi.org/10.1016/j.cedpsych.2020.101859.

Erlingsson, C., and P. Brysiewicz. 2017. "A Hands-On Guide to Doing Content Analysis.” African Journal of Emergency Medicine 7: 93-99. https://doi.org/10.1016/j.afjem.2017.08.001.

Frenzel, A. C., T. Goetz, O. Lüdtke, R. Pekrun, and R. Sutton. 2009. "Emotional Transmission in the Classroom: Exploring the Relationship between Teacher and Student Enjoyment." Journal of Educational Psychology 101: 705-16. https://doi.org/10.1037/a0014695.

Furrer, C., and E. Skinner. 2003. "Sense of Relatedness as a Factor in Children's Academic Engagement and Performance." Journal of Educational Psychology 95: 148-62. https://doi.org/10.1037/0022-0663.95.1.148.

Glesne, C. 2006. Becoming Qualitative Researchers. Boston: Pearson.

Goldsworthy, R. 2000. "Designing Instruction for Emotional Intelligence.” Educational Technology 40 (5): 43-48.

Graham, S. 2020. “An Attributional Theory of Motivation.” Contemporary Educational Psychology 61. https://doi.org/10.1016/j.cedpsych.2020.101861.

Hammer, D., and A. Elby. 2002. "On the Form of a Personal Epistemology." In Personal Epistemology: The Psychology of Beliefs about Knowledge and Knowing, edited by B. K. Hofer and P. R. Pintrich, 169-190. Mahwah: Lawrence Erlbaum.

Hannaway, D., P. Govender, P. Marais, and C. Meier. 2018. "Growing Early Childhood Education Teachers in Rural Areas." Africa Education Review 16 (3): 36-53. https://doi.org/10.1080/18146627.2018.1445974. 
Hara, N., and R. Kling. 2003. "Students' Distress with a Web-Based Distance Education Course: An Ethnographic Study of Participants' Experiences.” Turkish Online Journal of Distance Education 4 (2). Accessed 2 February 2021.

http://tojde.anadolu.edu.tr/tojde10/articles/hara.htm.

Järvenoja, H., and S. Järvelä. 2005. "How Students Describe the Sources of Their Emotional and Motivational Experiences during the Learning Process: A Qualitative Approach." Learning and Instruction 15 (5): 465-80. https://doi.org/10.1016/j.learninstruc.2005.07.012.

Linnenbrink-Garcia, L., E. A. Patall, and E. E. Messersmith. 2013. “Antecedents and Consequences of Situational Interest." British Journal of Educational Psychology 83: 591614. https://doi.org/10.1111/j.2044-8279.2012.02080.x.

Linnenbrink-Garcia, L., E. A. Patall, and R. Pekrun. 2016. "Adaptive Motivation and Emotion in Education: Research and Principles for Instructional Design." Policy Insights from the Behavioral and Brain Sciences 3: 228-36. https://doi.org/10.1177/2372732216644450.

MacFadden, R. J. 2007. “The Forgotten Dimension in Learning: Incorporating Emotion into Web-Based Education." Journal of Technology in Human Services 25 (1-2): 85-101. https://doi.org/10.1300/J017v25n01_05.

MacFadden, R. J., M. Herie, S. Maiter, G. Dumbrill. 2005. “Achieving High Touch in High Tech: A Constructivist, Emotionally Oriented Model of Web-Based Instruction." Journal of Teaching in Social Work 25 (1/2): 21-44. https://doi.org/10.1300/J067v25n01_02.

Moorhouse, B. L. 2020. “Adaptations to a Face-To-Face Initial Teacher Education Course 'Forced' Online due to the COVID-19 Pandemic." https://doi.org/10.1080/02607476.2020.1755205.

Olivia, N. 2017. "What is Trustworthiness in Qualitative Research?" Accessed 6 December 2020. https://www.coursehero.com/file/p46d3mf/2017-EstablishingTrustworthiness-in-Qualitative-Research.

O’Regan, K. 2003. "Emotion and E-Learning.” Journal of Asynchronous Learning Networks 7 (3): 78-92.

Pekrun, R. 2006. "The Control-Value Theory of Achievement Emotions: Assumptions, Corollaries, and Implications for Educational Research and Practice." Educational Psychology Review 18: 315-41. https://doi.org/10.1007/s10648-006-9029-9.

Pekrun, R., T. Goetz, A. C. Frenzel, P. Barchfeld, and R. P. Perry. 2011. "Measuring Emotions in Students' Learning and Performance: The Achievement Emotions Questionnaire (AEQ)." Contemporary Educational Psychology 36 (1): 36-48. https://doi.org/10.1016/j.cedpsych.2010.10.002. 
Rovai, A., and M. Wighting. 2005. "Feelings of Alienation and Community among Higher Education Students in a Virtual Classroom." Internet and Higher Education 8 (2): 97-110. https://doi.org/10.1016/j.iheduc.2005.03.001.

Ryan, R. M., and E. L. Deci. 2020. "Intrinsic and Extrinsic Motivation from a Self-

Determination Theory Perspective: Definitions, Theory, Practices, and Future Directions." Contemporary Educational Psychology 61. https://doi.org/10.1016/j.cedpsych.2020.101860.

Ryan, R. M., and W. S. Grolnick. 1986. "Origins and Pawns in the Classroom: Self-Report and Projective Assessments of Individual Differences in Children's Perceptions." Journal of Personality and Social Psychology 50: 550-58. https://doi.org/10.1037/00223514.50.3.550.

Spitzer, D. R. 2001. "Don't Forget the High-Touch with the High-Tech in Distance Learning." Educational Technology 41 (2): 51-55.

Urdan, T., and A. Kaplan. 2020. "The Origins, Evolution, and Future Directions of Achievement Goal Theory." Contemporary Educational Psychology 61. https://doi.org/10.1016/j.cedpsych.2020.101862.

Wosnitza, M., and S. Volet. 2005. "Origin, Direction and Impact of Emotions in Social Online Learning." Learning and Instruction 15 (5): 44. https://doi.org/10.1016/j.learninstruc.2005.07.009.

Yin, R. K. 2009. Case Study Research: Design and Methods. 5th ed. Thousand Oaks: Sage.

Yorks, L., and E. Kasl. 2002. "Toward a Theory and Practice for Whole-Person Learning: Reconceptualizing Experience and the Role of Affect." Adult Education Quarterly 52 (3): 176-92. https://doi.org/10.1177/07417136020523002.

Zeichner, K. 1999. "The New Scholarship in Teacher Education.” Educational Researcher 28 (9): 4-15. https://doi.org/10.3102/0013189X028009004.

Zembylas, M. 2008. “Adult Learners' Emotions in Online Learning.” Distance Education 29 (1): 71-87. https://doi.org/10.1080/01587910802004852. 


\section{Appendix A}

Dear Student,

We are living in extraordinary times owing to the Covid-19 pandemic. The measures taken to curb the pandemic have drastically changed many aspects of our daily lives. We would like you to participate in a survey that will help us understand your learning needs and, in particular, your emotional challenges during the lockdown. The survey is voluntary and you are welcome to discontinue participation at any point.

Your responses are completely anonymous and all reporting will be done at an aggregated level to protect your identity.

1. To which population group do you belong?
C African
Coloured
Indian
C White
C Prefer not to disclose
C Other

2. What is your gender?

C Female

C Male

C Prefer not to disclose

3. What is your age? ........

4. Rate how easy it is for you to study at your place of residence during the Covid-19 pandemic.

Select a value between 1.0 and 10.0

0.0

5. How satisfied are you with the online academic activities so far?

C Extremely satisfied

Satisfied

C Neither satisfied nor dissatisfied

C Dissatisfied

Extremely dissatisfied 
6. With which aspects did you experience the most challenges, such as administration, student support, online learning, completing assignments or answering exam papers?

7. Which of the following tool(s) do you have access to in order to participate in online academic activities?

Please select no more than 5 options.

Г Laptop

Г Mobile phone

$\lceil\quad$ Sufficient data for studies

Г Broadband internet access

Г Access to videoconference account

Г Access to teleconference account

Г Access to myUniversity Online Account/Portal

Give reasons for your choices:

8. Which of the following services from (the institution) do you need to participate in online academic activities?

O Online lectures

- Assignment submission

- Financial services

$\circ$ e-Tutorials

- Study material download

- Email supervision

- Administrative services

- Graduation services

9. What else do you need to be able to participate in all online academic activities?

10. How else can we improve your online learning experience during the lockdown?

11. What additional questions or concerns do you have at this time? 
12. In the past five months, which emotion did you feel most often?
○ Happy
- Contented
- Excited
○ Restless
- Sad
$\circ$ Worried
$\circ$ Angry
- Other (please specify)

13. What event or events caused you to feel that emotion most frequently?

14. Which response below best describes you in academic work? Why? Please use the Other box to explain why.

- I keep my emotions to myself.

- I share my emotions only with my family.

- I share my emotions only with my friends.

- I share my emotions with family and friends.

- Other (please specify) 